\title{
Hydration Status and Cardiovascular Function
}

\author{
Joseph C. Watso *(D) and William B. Farquhar \\ Department of Kinesiology and Applied Physiology, University of Delaware, Newark, DE 19713, USA \\ * Correspondence: JosephWatso@texashealth.org; Tel.: +1-214-345-4852
}

Received: 22 June 2019; Accepted: 8 August 2019; Published: 11 August 2019

\begin{abstract}
Hypohydration, defined as a state of low body water, increases thirst sensations, arginine vasopressin release, and elicits renin-angiotensin-aldosterone system activation to replenish intraand extra-cellular fluid stores. Hypohydration impairs mental and physical performance, but new evidence suggests hypohydration may also have deleterious effects on cardiovascular health. This is alarming because cardiovascular disease is the leading cause of death in the United States. Observational studies have linked habitual low water intake with increased future risk for adverse cardiovascular events. While it is currently unclear how chronic reductions in water intake may predispose individuals to greater future risk for adverse cardiovascular events, there is evidence that acute hypohydration impairs vascular function and blood pressure (BP) regulation. Specifically, acute hypohydration may reduce endothelial function, increase sympathetic nervous system activity, and worsen orthostatic tolerance. Therefore, the purpose of this review is to present the currently available evidence linking acute hypohydration with altered vascular function and BP regulation.
\end{abstract}

Keywords: hypohydration; vascular function; sympathetic nervous system; blood pressure regulation

\section{The Physiology of Hypohydration}

Hypohydration is defined as a body water deficit caused by acute or chronic dehydration [1]. While extensive research has been conducted to identify the "elusive daily water requirement", well summarized by Armstrong and Johnson [2] within this special issue, acute hypohydration studies have provided important insight into the integrative physiology of water balance in humans. Human hypohydration can be elicited experimentally through the use of water restriction, prolonged exercise, heat stress, diuretic administration, or a combination of methods [3-31]. In response to hypohydration-induced reductions in plasma volume and increases in plasma sodium $\left(\left[\mathrm{Na}^{+}\right]\right) /$osmolality, the renin-angiotensin-aldosterone system becomes activated, thirst sensations increase, and arginine vasopressin (AVP, also referred to as anti-diuretic hormone) release increases [20,32-40]. A low extracellular fluid volume is sensed in the walls of the afferent arterioles proximal to the glomeruli and causes juxtaglomerular cells to secrete renin, which initiates a cascade culminating in increased circulating angiotensin II (Ang II) and aldosterone concentrations acting to increase $\left[\mathrm{Na}^{+}\right]$and water retention. Central $\left[\mathrm{Na}^{+}\right]$sensing, which may be distinct from osmo-sensing [41], occurs in circumventricular organs including the organum vasculosum of the lamina terminalis (OVLT) and subfornical organ (SFO) because both brain areas lack a complete blood-brain barrier (BBB) [42]. Specialized mechanical-stretch transient receptor potential vanilloid (TRPV) cation channels are one potential candidate thought to participate in osmo-sensing [43]. Nevertheless, these signals are communicated through neuronal projections to the median preoptic nucleus $(\mathrm{MnPO})$ before activating thirst-promoting neurons in the paraventricular nucleus (PVN) of the hypothalamus via acid-sensing ion channel 1a (ASIC1a) by $\mathrm{H}^{+}$ions exported from $\mathrm{Na}_{\mathrm{x}}$-positive glial cells [44]. These signals are then 1) relayed to the lateral hypothalamus as well as the paraventricular hypothalamus and thalamus [45], and 2) stimulate AVP release from the posterior pituitary gland from upstream 
communication with the PVN and supraoptic nuclei [34,46]. Increased thirst sensations promote water intake $[45,46]$. Increased plasma [AVP] stimulate aquaporin-2-mediated water reabsorption from the luminal surface of renal collecting ducts to promote water retention [47]. Together, these integrated responses aim to restore body water homeostasis.

The following sections will discuss recent findings related to hypohydration and cardiovascular function. When applicable, we will mention the methods used to induce hypohydration (e.g., heat, exercise, fluid restriction, or diuretic) in humans because these methods have different side effects (e.g., diuretics promote iso-osmotic hypovolemia whereas heat stress promotes hyper-osmotic hypovolemia) [48]. Finally, for human hypohydration studies, we will report the resultant body mass deficit as the severity of hypohydration is defined as follows: mild hypohydration (1 to 5\% body mass deficit), moderate hypohydration (5 to 10\% body mass deficit), and severe hypohydration ( $>10 \%$ body mass deficit) [1].

\section{Clinical Relevance}

As early as 1933, insufficient body water stores were identified as a primary factor for heat exhaustion and fatigue, with scientists concluding, "Most people need the advice: Drink more water" [49]. Approximately a decade later, two scientists deprived themselves of water for over three days and became, "temperamental, hollow, and pale." Despite noting, "dry mouths, husky voices, and difficulty swallowing," the authors were, "never unbearably thirsty." While this prolonged fluid deprivation would now have major ethical concerns, this experiment serves as an early example of how a lack of fluid intake alone can elicit substantial $(\sim 5 \%)$ reductions in body mass and large $(\sim 10 \%)$ increases in plasma $\left[\mathrm{Na}^{+}\right]$[9].

While one 2019 report acknowledges that the field has yet to agree on the biomarker(s) and cutoff(s) that define euhydration (optimal total body water content [1]), only 13 to $51 \%$ of individuals studied (depending on sex, age group, and disease status) met the authors hydration criteria [50]. Additionally, Americans are not meeting water intake recommendations [51], which is alarming as inadequate water intake is associated with obesity [52] and predicts greater future risk for developing cardiovascular disease [53], the leading cause of death in the United States [54]. Additionally, suboptimal water intake has been demonstrated to enhance serum- and glucocorticoid-inducible kinase 1 activity (SGK1), which participates in the pathophysiology of a number of disease states including hypertension, thrombosis, stroke, and cardiac fibrosis [55]. Further, there are data demonstrating a positive association between plasma $\left[\mathrm{Na}^{+}\right]$and 10-year risk of coronary heart disease in participants from the Atherosclerosis Risk in Community (ARIC) Study [56]. Some [57-59] but not all [60] epidemiological evidence suggests an association between greater plasma $\left[\mathrm{Na}^{+}\right]$and increased arterial blood pressure (BP).

While increasing age has been demonstrated to be associated with indices of reduced hydration status [61], the findings from one 2019 study suggest that increasing age is not associated with indices of reduced hydration status [50]. Nevertheless, there are several physiological reasons that old adults are less likely to have optimal hydration status including lower basal total body water [62], altered extracellular fluid sensing [63], blunted hormonal (e.g., AVP) responses [64,65], and impaired kidney function [66]. However, even within young healthy individuals, several investigations have provided evidence that acute hypohydration can significantly affect physiological function.

For example, there are well-appreciated deleterious effects of acute hypohydration including reduced exercise performance [3,4,10,12-14,16,67-88], worsened mood [18,89-91], impaired cognitive function [19-21,91,92], altered thermoregulatory function [73,74,80,82,84,87,93-108], and decreased glycemic regulation [11,109] (Figure 1). Chronic systemic hypohydration is a proposed pathogenic factor for hypertension, venous thromboembolism, fatal coronary heart disease, stroke [110]. However, there are relatively few randomized trials examining the effects of acute or chronic mild hypohydration on vascular function and BP regulation. Importantly, reduced vascular function [111-114], high resting BP (i.e., hypertension) [115], high BP variability [116-120], orthostatic intolerance [121,122], and exaggerated BP responses during exercise [123-127] are independent clinical predictors for adverse 
cardiovascular health outcomes. Thus, given the clinical relevance of this area of research, the purpose of this review is to present the currently available evidence on the effects of acute mild hypohydration on vascular function and BP regulation.

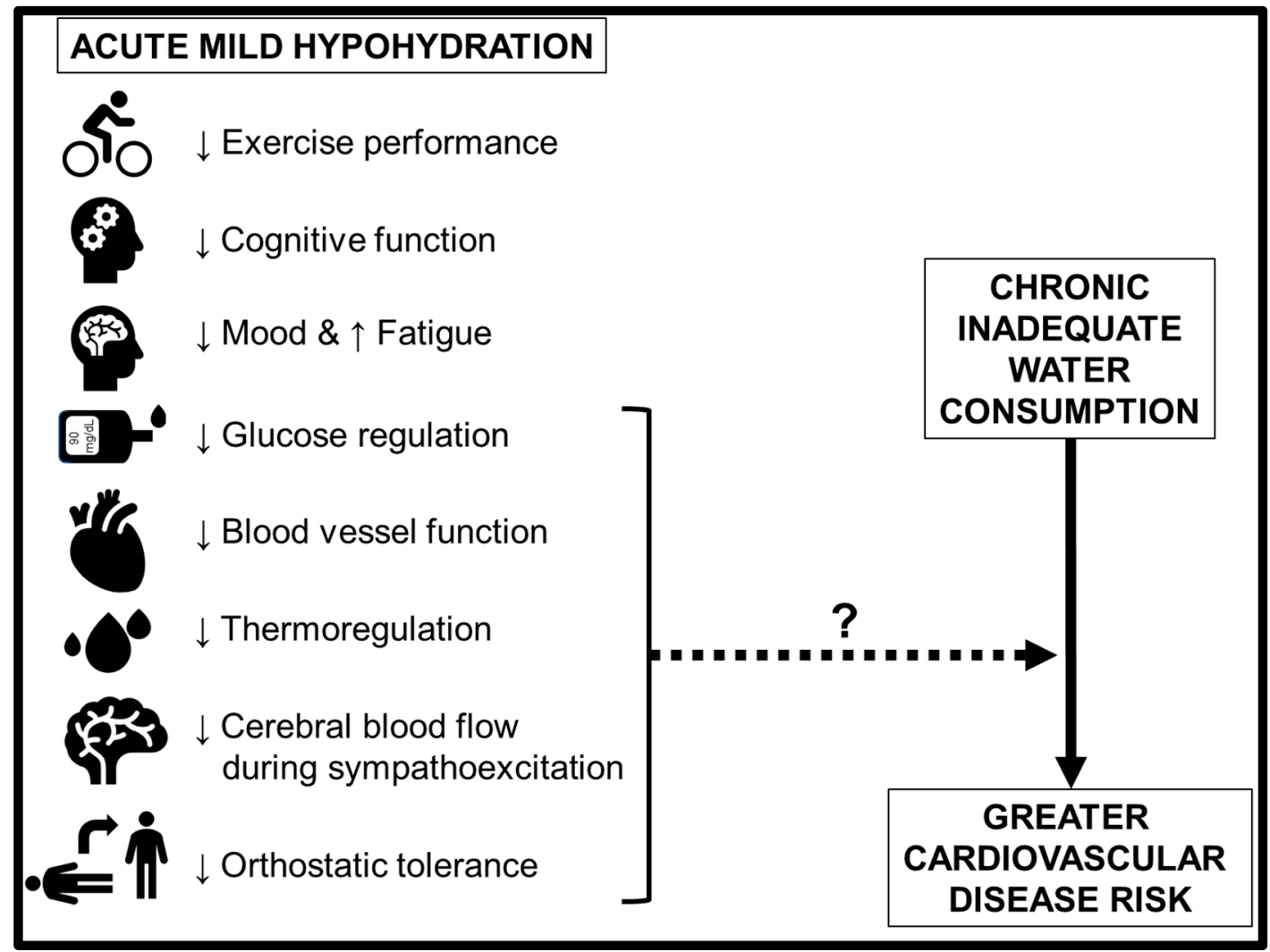

Figure 1. Summary of the physiological consequences of acute mild hypohydration in healthy humans. Further research is necessary to determine whether and how these acute effects influence the poor cardiovascular health outcomes associated with chronic inadequate water consumption. $\downarrow$, impaired or reduced; $\uparrow$, increased.

\section{Vascular Health and Function}

\subsection{Inflammation}

As discussed above, hypohydration is characterized by elevated plasma [ $\left.\mathrm{Na}^{+}\right]$. Dmitrieva et al. [56] demonstrated that Human Primary Umbilical Endothelial Cells (HUVEC) exposed to media with increasing [ $\mathrm{NaCl}$ ] (several concentrations ranging from 270 to $380 \mathrm{mOsm} / \mathrm{kg} \mathrm{H}_{2} \mathrm{O}$ ) for 4 days were found to have significant increases in the mRNA expression of several pro-inflammatory mediators including vascular cell adhesion molecule 1 (VCAM-1), endothelial-leukocyte adhesion molecule 1 (E-selectin), and monocyte chemoattractant protein 1 (MCP-1). The authors performed additional experiments in rodents to elucidate the effects of physiological increases in $\left[\mathrm{Na}^{+}\right]$in vivo. Nine days of water restriction increased serum $\left[\mathrm{Na}^{+}\right]$by $\sim 5 \mathrm{mM}$ without altering body mass and the increased mRNA expression of VCAM-1, E-selectin, and chemokine MCP-1 in several tissues (e.g., liver, spleen, kidney). Additionally, VCAM-1 protein expression was increased in endothelial cells of liver capillaries and coronary arteries. Because long-term inflammation could increase the risk for the development of atherosclerotic lesions, the authors performed a final experiment in mice. ApoE ${ }^{-/-}$mice were fed a Western diet for 7-9 weeks with water intake ad libitum or restricted. The authors demonstrated a greater development of atherosclerotic lesions in the aortic root and thicker walls of their coronary arteries in water-restricted mice, suggesting prolonged water restriction may contribute to unfavorable vascular health [56]. Costa et al. [128] sought to determine whether hypohydration worsened the inflammatory profile in 
healthy humans. In randomized crossover fashion, participants either maintained euhydration or had water restricted (hypohydration, $\sim 3 \%$ reduction in body mass) while running at an ambient temperature $\left(25^{\circ} \mathrm{C}\right)$ on two separate occasions. The authors reported modest disturbances in gastrointestinal integrity and function as well as in-vitro neutrophil functional responses, but no effect on post-exercise total or differential leukocyte counts, endotoxemia, or cytokinemia following the hypohydration trial. The authors suggested that when taken together, this mild degree of hypohydration was insufficient to induce immune functional or cytokine responses of clinical significance [128]. While this human study was carried out with healthy endurance-trained adults, future studies investigating the influence of reduced water intake alone (i.e., not exercise induced) on the immune system in preclinical and clinical populations are warranted.

\subsection{Endothelial Function}

Endothelial dysfunction is a clinically significant marker of cardiovascular health $[111,112,114]$. There are cellular studies demonstrating that hypernatremia (high $\mathrm{Na}^{+}$concentrations in fluid) results in degradation of the endothelial glycocalyx, which may also contribute to impaired endothelial responsiveness to shear stress [129]. Arnaoutis et al. [27] sought to determine whether hypohydration impairs peripheral artery vasodilatory function in healthy young male adults. A $\sim 2 \%$ reduction in body mass was achieved with 100 minutes of low-intensity (70\% of maximal heart rate) walking in mild heat $\left(31^{\circ} \mathrm{C}\right)$ with a $500-\mathrm{mL}$ water intake limit for the remainder of the day. Compared to the same perturbation without a water intake limit, participants demonstrated reduced flow-mediation dilation (FMD, an assessment of endothelial-dependent vasodilatory function) in the water-restricted state [27]. The authors acknowledge the limitation that blood viscosity was not assessed but could have been increased during hypohydration. This is relevant because some published data suggest blood viscosity does affect FMD values [130] but other data suggest that shear rate (blood velocity/vessel diameter) is a weaker correlate of FMD than shear stress (blood viscosity*blood velocity/vessel diameter) [131]. Nevertheless, shear stress was not different between conditions at baseline or during hyperemia [27]. Additionally, while it is unlikely that FMD values in the present study [27] were affected by exercise 24 hours prior [132], future investigations examining the effects of water restriction alone on endothelial function are warranted. Finally, these future studies should be carried out in both male and female adults.

\subsection{Arterial Stiffness}

Aortic stiffness expressed as aortic pulse wave velocity (PWV) is a strong predictor of future cardiovascular events and all-cause mortality [133]. One study examined whether hypohydration-induced via 24 -hour fluid restriction or acute heat stress $\left(49^{\circ} \mathrm{C}\right.$ water in perfused suit) affects PWV in healthy humans [26]. Caldwell et al. reported that 24-hour fluid restriction in young female adults elicited a $\sim 1 \%$ reduction in body mass and reduced central, but not peripheral, PWV compared to the euhydrated control condition. In the same article, a cohort of young male adults underwent whole-body heating to increase rectal temperature $+1.0^{\circ} \mathrm{C}$ and had fluid intake restricted, resulting in a $\sim 2 \%$ body mass loss relative to when participants repeated the whole-body heating on a separate occasion but ingested water to prevent body mass loss. Despite the presence of mild hypohydration in the water-restricted state, participants had similar reductions in peripheral PWV throughout heat stress regardless of condition. Finally, central PWV did not change during acute heat stress in either group [26]. These findings suggest that fluid restriction-induced hypohydration reduces central PWV and heat stress-induced hypohydration does not change central PWV. The authors purposefully designed the study to include homogenous groups because their pilot testing demonstrated large sex-related differences in resting PWV values that would have made the interpretation of findings much more difficult as biological sex could be as important of a factor for altering PWV as the technique used to elicit hypohydration [26]. Thus, it remains unclear whether fluid restriction in males or heat-stress and water restriction in females elicits similar responses. 


\subsection{Cutaneous Vascular Function}

There is evidence that mild hypohydration (at either 1\% [22] or 3\% [23] body mass loss) impairs cutaneous vasodilation during exercise in the heat following fluid restriction in healthy male adults. More recent work suggests that hypohydration-induced reductions in skin blood flow are at least partially attributed to altered postsynaptic function in healthy young male adults. This hypothesis is supported by evidence that more methacholine chloride (an endothelium-dependent vasodilator) is required to achieve the drug concentration that provides half of the maximal response $\left(\mathrm{EC}_{50}\right)$ during hypohydration to $\sim 2 \%$ body mass loss via exercise in the heat following fluid restriction compared to euhydration [25]. While only one [22] of these particular three studies examining vascular function $[22,23,25]$ reported greater increases in body temperature in the hypohydrated state, several other studies have found hydration status to affect thermoregulatory function $[73,74,80,82,84,87,93-108,134]$. As a result, specific guidelines for hydration status have been set in certain populations, such as industrial workers in the heat [135], to minimize the potential for heat-stress and hypohydration-induced increases in cardiovascular strain and potential risk for adverse cardiovascular events. For further discussion on this topic, the reader is directed to several excellent reviews on the interactions between hydration and thermoregulation [70-72,103,136-138]. Additional work in this area is warranted, particularly studies that include female adults.

\subsection{Circulating Factors}

During hypohydration, elevated plasma [Ang II] elicits vasoconstriction in small arterioles to increase total peripheral resistance [139] and is thought to contribute to endothelial dysfunction [140]. Specifically, Ang II infusion elicits endothelial dysfunction in rodents [141-144] and stimulates NADPH oxidase (NOX)-mediated increases in reactive oxygen species (ROS) in smooth muscle cells from human resistance arterioles $[145,146]$. Further, data from rodent models suggest that hypohydration increases Ang II receptor density and affects neuronal nitric oxide synthase (nNOS) mRNA expression [147]. These data suggested that Ang II blockade may reduce oxidative stress and improve vascular function in humans. In support of this hypothesis, one study reported that Ang II blockade (candesartan) reduced oxidative stress and improved FMD in hypertensive adults [148]. More recent evidence suggests that Ang II blockade reduces inflammation and improves peripheral vascular function in healthy and clinical populations [149-153]. For an extended discussion on the effects of Ang II blockade on vascular function in hypertensive adults, the reader is directed to a recent review article on this topic [154].

Results from one rodent study suggest that increased plasma [AVP] during hypohydration contributes to the production of ROS, elicits cerebrovascular dysfunction (via reduced vasodilator function as assessed by increasing doses of acetylcholine (Ach)), and cognitive dysfunction as AVP receptor antagonist SR49059 prevents these changes following 48 hours of water deprivation in rodents [20]. Hypohydration has also been demonstrated to increase plasma [endothelin-1] in both rodents [155] and humans [156]. This could be problematic as greater plasma [endothelin-1] has been associated with reduced peripheral vasodilatory function $[157,158]$. Interestingly, the neocortical application of endothelin receptor type $\mathrm{A}\left(\mathrm{ET}_{\mathrm{A}} \mathrm{R}\right)$ antagonist $\mathrm{BQ123}$ ameliorates the cerebrovascular dysfunction induced by 48 hours of water deprivation in rodents [20]. Collectively, these data support a role for hypohydration influencing circulating factors that contribute to reduced blood vessel function.

\subsection{Summary}

There is a growing body of evidence that hypohydration induces inflammation, reduces endothelial function, and may affect measures of arterial stiffness in humans. Additionally, changes in several circulating factors during acute hypohydration may mediate changes in vascular function and BP regulation. The following sections will discuss the influence of acute hypohydration on cerebral blood flow regulation as well as BP regulation at rest, during orthostasis, and during exercise. 


\section{Cerebral Blood Flow Regulation}

There are several reports of hypohydration being associated with worsened mood [18,89-91] and impaired cognitive function [19-21,91,92] that have prompted investigation into how acute hypohydration affects cerebral blood flow patterns. Tan et al. [87] had 10 male adults undergo magnetic resonance imaging (MRI) brain scans before running in ambient temperature $\left(\sim 25^{\circ} \mathrm{C}\right)$ with a raincoat on to elicit a $\sim 3 \%$ reduction in body mass on two occasions. Following exercise, participants either drank water to offset body mass loss or were restricted from fluid intake. During the second MRI brain scan 90 minutes after exercise, hypohydration produced reductions in total brain volume (total intracranial volume excluding ventricles) and increases in brain ventricular volume. However, there were no observed changes in global or regional brain perfusion, or functional activity of the brain during a motor-task based functional MRI (fMRI) scan during hypohydration [87]. Trangmar et al. [31] reported that incremental cycling exercise to exhaustion in the heat $\left(35^{\circ} \mathrm{C}\right)$ in 10 endurance-trained male adults elicited a $\sim 3 \%$ reduction in body mass and lowered internal carotid and middle cerebral artery mean velocity $\left(\mathrm{MCA}_{\mathrm{vmean})}\right.$ without affecting common carotid artery blood flow during exercise. However, when tested in the euhydrated state on a separate day, internal carotid and middle cerebral artery mean velocity and common carotid blood flow were preserved. This augmentation of hypohydration-induced decline in cerebral blood flow was reported to result from decreasing arterial carbon dioxide tension, which enhanced vasoconstrictor activity. Despite the reductions in cerebral blood flow, the cerebral metabolic rate for oxygen was maintained in the hypohydrated condition as a result of increased oxygen extraction [31]. Reductions in $\mathrm{MCA}_{\mathrm{vmean}}$ and end-tidal carbon dioxide partial pressure $\left(\mathrm{P}_{\mathrm{ET}} \mathrm{CO}_{2}\right)$ have also been observed during a two-foot immersion cold pressor test in hypohydrated young male adults ( $1 \%$ body mass loss via 24-hour fluid restriction) [159]. Together, these studies suggest that mild hypohydration in healthy young male adults is associated with alterations in cerebral blood flow regulation during acute sympathoexcitation (e.g., maximal exercise, the cold pressor test). Because hypohydration has been associated with reductions in cognitive function [19-21,92], more work in this area is warranted and future study designs should prioritize the inclusion of female adults.

\section{Resting Cardiovascular Regulation}

\subsection{Sympathetic Nervous System}

Aside from promoting thirst and stimulating renal water reabsorption, signals of high central $\left[\mathrm{Na}^{+}\right]$are relayed to the rostral ventrolateral medulla (RVLM) and can affect BP through increases in sympathetic outflow [160-162]. During water deprivation in rats, blood hyperosmolality (i.e., elevated blood osmolality values) was found to influence sympathetic outflow and BP, independent of changes in plasma [AVP] and blood volume [163]. This is likely due to greater sensitivity of the PVN during times of blood hyperosmolality, demonstrated through studies using injections of $\gamma$-Aminobutyric acid (GABA) agonists and glutamate antagonists [32] and studies investigating changes to the intrinsic properties of RVLM neurons [160]. In support of these past reports, hypohydrated rats were found to have BP supported by PVN-driven increases in splanchnic sympathetic outflow that is not synchronized to changes in respiration or heart rate [161]. This is thought to occur from central hyperosmolality exciting discrete populations of neurons in the RVLM that increase sympathetic outflow and BP through the increased sensitivity of glutamate neurotransmission [162]. Importantly, alterations in sympathetic outflow and $\mathrm{BP}$ during central hyperosmolality are related to $\mathrm{NaCl}$ concentrations per se, as eqiu-osmotic sorbitol or mannitol does not produce the same OVLT neuronal discharge frequency [41]. Other animal studies suggest that activator protein-1 transcription factors are responsible for switching thoracic sympathetic outflow control from the hypothalamus to the commissural nucleus tractus solitarius (NTS) following water deprivation [164]. Blocking sympathetic outflow attenuates the BP elevations induced by high cerebrospinal fluid $\left[\mathrm{Na}^{+}\right]$in rodents [162]. Nonetheless, potential sensing mechanisms for $\left[\mathrm{Na}^{+}\right]$existing in the brain have been elucidated using rodent models [162,164-166]. A newly published study adds additional mechanistic insight, suggesting that Nax-positive glial 
cells in OVLT are activated by high $\left[\mathrm{Na}^{+}\right]$, leading to enhanced hydrogen and lactate through a monocarboxylate transporter to activate ASIC1a-positive OVLT neurons [43]. More recently, one study in rodents demonstrated that sympathetic blockade (via $\alpha 1$ - and $\beta 1$ - adrenergic receptor antagonists) significantly attenuated the increases in resting BP following 48 hours of water deprivation [165]. Together, these studies have provided insight into the role of the sympathetic nervous system activation to support BP during hypohydration.

\subsection{Circulating Factors}

Reduced sympathetic baroreflex function is associated with hypertension [166] and reduced cardiac vagal baroreflex sensitivity is associated with increasing age $[167,168]$. Importantly, reductions in baroreflex function can increase (i.e., worsen) BP variability, which is associated with cardiovascular morbidities such as cerebral small vessel disease [169], increased carotid artery intima-media thickness [170], target organ damage [117,171], hypertensive status [172], and cardiovascular mortality $[119,120]$. However, to date, only one study has investigated the influence of hypohydration on BP variability [173]. This study reported that iso-osmotic hypovolemia via furosemide (no body mass data reported) did not change the power spectral density of mean BP, a measure of BP variability in the frequency domain. One study in humans administered exogenous Ang II and observed increases in muscle sympathetic nerve activity (MSNA) [174]. Rabbitts et al. [28] used a 24-hour water restriction model in healthy young adults to elicit increases in endogenous [Ang II]. While body mass data following the water restriction protocol were not reported, resting MSNA burst incidence was reportedly increased with no change in resting BP. Despite increased MSNA burst incidence, both sympathetic and cardiac vagal baroreflex sensitivity were unchanged following water restriction [28]. This finding that water restriction in humans does not alter arterial baroreflex sensitivity is consistent with one previous study in 48-hour water-deprived rabbits [175]. Interestingly, in the human study, the water restriction-mediated increase in MSNA burst incidence was attenuated after the administration of losartan (an angiotensin receptor blocker), suggesting elevated [Ang II] produced endogenously provoked increases in sympathetic outflow [28]. Another study investigating the effects of hypohydration ( $2 \%$ body mass loss) on baroreflex function noted a tendency for lower sympathetic baroreflex gain following hypohydration induced by 90 minutes of acute aerobic exercise compared to exercise and intravenous rehydration 20-25 minutes later [176]. While insightful, these data could have potentially been influenced by the prior bout of exercise (collected about 45-60 minutes post exercise). Together, these studies also report conflicting results regarding the influence of hypohydration on arterial baroreflex function. Thus, additional research would provide helpful insight. Further, research investigating the influence of hypohydration on BP variability is warranted.

During hypohydration, elevations in plasma [AVP] (tightly linked to changes in plasma osmolality [17]) and [Ang II] contribute to the maintenance of BP through numerous mechanisms [32,35-37,40,175,177]. For example, hypohydration in rats has been demonstrated to increase plasma renin activity, even during renal denervation and adrenal demedullation, suggesting sympathoadrenomedullary-independent plasma renin activity release to support BP [37]. When plasma renin activity is increased during hypohydration, angiotensin type- 1 receptors in the PVN and RVLM are thought to become more sensitive [32], suggesting the renin-angiotensin-aldosterone axis mediates alterations in BP control through interaction with central cardiovascular control centers (i.e., the RVLM). Excessive AVP release has been suggested to play a role in glucoregulatory health [178] and in the development of human hypertension [179]. For a general review on the influence of AVP in cardiovascular control, the reader is directed to a review by Liard [180].

During hypovolemia, AVP is released via actions of the forebrain and midbrain [181] and supports BP by increasing lumbar sympathetic outflow and heart rate [163], independent of the involvement of the subfornical organ [182]. AVP blockade following water deprivation causes a significant drop in BP, suggesting its actions are necessary for BP support during water deprivation (WD) [177,183]. Rodent models using intravenous AVP antagonism demonstrate attenuated pressor and bradycardic 
effects of $\alpha 1$-adrenergic receptor agonists (e.g., methoxamine, phenylephrine) [184]. AVP antagonism in dogs attenuates the depressor and tachycardic effects of systemic nitric oxide-mediated vasodilation (via sodium nitroprusside), with no additive effect of Ang II antagonism, suggesting AVP plays a primary role in BP control during hypotensive insults [185]. In agreement, one study in rats demonstrated that the administration of intravenous synthetic AVP increases BP following water deprivation [40]. Further, Aisenbrey et al. [40] demonstrated that AVP blockade in rats lowers BP via reductions in peripheral vascular resistance, and this occurs independent of cardiac or arterial baroreceptor input [186]. In contrast, one previous study in rats reported that after 24 or 48 hours of water deprivation, AVP did not significantly contribute to BP maintenance [187]. There is also evidence that AVP only has a minor influence on BP support following hypohydration in humans ( $2 \%$ body mass loss via 24-hour fluid restriction), as selective V1 receptor antagonist [d(CH2)5Tyr(ME)]AVP elicited only minor reductions in diastolic BP and cardiac preload [188]. Together, the conflicting results in the literature regarding the influence of Ang II and AVP on BP regulation during hypohydration suggests more investigation in this area is necessary. Finally, several studies that have been conducted regarding the influence of biological sex [189-198] and sex hormone fluctuations during the menstrual cycle in female adults [189,191-197] and BP regulation. These studies have provided important insight concerning the influence of sex and menstrual cycle-induced changes in blood volume on BP regulation, which is a prerequisite to studying the additional influence of hypohydration. In summary, several circulating factors appear to influence resting BP regulation and the discrepancies in findings may be related to species differences as well as the method and degree of hypovolemia/hypohydration.

\section{Cardiovascular Regulation During Orthostatic Stress}

Orthostatic stress in humans occurs during daily life when posture changes from the supine or seated positions to the standing position. Approximately $500 \mathrm{~mL}$ of blood pools in lower body venous circulation immediately upon changing from the supine to the upright position [199]. To maintain $\mathrm{BP}$ and adequate cerebral perfusion upon standing, the body relies on rapid baroreflex-mediated increases in heart rate and MSNA. Without appropriate mechanisms to regulate BP during standing, there is an increased risk of syncope (i.e., fainting), which can result in an injury. While estimates vary among epidemiological studies, it has been reported that approximately $\sim 10 \%$ of the population is orthostatic intolerant, defined as having significant drops in systolic and/or diastolic BP upon standing [200]. As a result of the obvious health concerns of syncope and head injuries, there has been a great amount of investigations aimed to determine the internal (i.e., physiological) and external (i.e., ambient temperature) factors that contribute to orthostatic intolerance because it is associated with adverse cardiovascular health outcomes [121,122]. For more details regarding the prognosis and treatment of orthostatic intolerance, the reader is directed to the following review article [201].

Experimentally, head-up tilt testing and lower body negative pressure (LBNP) challenges are commonly used to assess the integrated physiological responses that occur during orthostatic stress. The common factor among standing, head-up tilt testing, and LBNP is progressive central hypovolemia and, for this reason, head-up tilt testing [202] and LBNP [203,204] are valid models for assessing orthostatic tolerance, and can be affected by hydration status [30]. There are detailed reviews available that discuss the clinical applications of head-up tilt testing [205] and LBNP [206].

Related to hypohydration, one study from 1990 used furosemide (iso-osmotic hypovolemia) to elicit a $\sim 2 \%$ body mass loss in healthy male adults. These participants demonstrated increased gain in cardiopulmonary baroreflex during a head-up tilt testing challenge (i.e., larger increase in vascular resistance for a given decrease in central venous pressure) [207]. Later, Cheuvront et al. [208] demonstrated that moderate hypertonic hypohydration ( $\sim 5 \%$ body mass loss via exercise in the heat $\left(40^{\circ} \mathrm{C}\right)$ ) and mild isotonic hypohydration $(\sim 3 \%$ body mass loss via furosemide), but not mild hypertonic hypohydration $\left(\sim 3 \%\right.$ body mass loss via exercise in the heat $\left.\left(40^{\circ} \mathrm{C}\right)\right)$, significantly increased sit-to-stand-induced changes in heart rate in healthy male and female adults. Work that is more recent has indicated that in response to a head-up tilt challenge, iso-osmotic hypovolemia ( $\sim 3 \%$ body mass 
loss via furosemide) modulates heart rate and hyperosmotic hypovolemia ( $3 \%$ body mass loss via exercise in the heat $\left(40^{\circ} \mathrm{C}\right)$ ) modulates both heart rate and MSNA to support BP in healthy male and female adults [6]. Iso-osmotic hypovolemia via aldosterone receptor antagonist spironolactone (Aldactone; no body mass loss data reported) in healthy young males has been demonstrated to augment changes in total MSNA and total peripheral resistance during orthostasis to compensate for plasma volume (16\% reduction) contraction-induced decrements in stroke volume and cardiac output [29]. A later published analysis of these data demonstrated that MSNA burst amplitude but not MSNA burst frequency mediated the observed increases in MSNA total activity during LBNP [209]. These studies demonstrate that plasma volume deficits imposed by hypohydration (e.g., reductions in plasma volume and increases in plasma osmolality) elicit alterations in the complex integrative cardiovascular responses that occur during an orthostatic challenge. Given that orthostatic intolerance is more common in female adults [200] and this research concerning hypohydration and cardiovascular responses to orthostatic challenges has been completed in young male adults, additional work in female adults and older populations are warranted.

\section{Cardiovascular Regulation During Exercise}

Skeletal muscles require increased blood flow during exercise. Appropriate alterations in BP allow for increased blood flow to active skeletal muscle beds for the delivery of nutrients (e.g., oxygen) and for removal of metabolic byproducts (e.g., lactate). Augmented increases in BP during exercise is associated with greater future incidence of hypertension [124-126], as well as greater cardiovascular [123] and cardiometabolic [127] disease risk. Studies in rodents demonstrate that the hindbrain is responsible for mediating autonomic cardiovascular reflexes during hypovolemia to maintain BP [181]. Following 48 hours of water deprivation in rats, BP responses to unilateral RVLM microinjection of L-glutamate have been reported to be augmented, suggesting the increased sensitivity of RVLM neurons to excitatory amino acids during severe dehydration in rodents [210]. However, in our recent study, while 48 hours of WD in rodents increased resting lumbar sympathetic outflow and BP as previously reported in other studies [211], we did not observe water deprivation to change the responsiveness of sympathetic-regulatory neurons in the RVLM to the exogenous application of L-glutamate (sympathoexcitatory) or GABA (sympathoinhibitory) [212]. While the reasons for the discrepancies in findings between the former study [210] and our recent study [212] are unclear, we speculated that because injections were unilateral, intact compensatory contralateral pathways could have contributed to divergent observations. Nevertheless, additional work is warranted to provide insight into these autonomic cardiovascular responses following water deprivation.

In humans, moderate osmotic hypohydration ( 5\% body mass loss via cycling in the heat $\left.\left(35^{\circ} \mathrm{C}\right)\right)$ has been demonstrated to attenuate the exercise-induced increases in BP, primarily by attenuating increases in cardiac output. One study in male adults demonstrated greater increases in heart rate and plasma $[\mathrm{AVP}]$ during exercise following mild hypohydration ( $3 \%$ body mass loss via cycling in the heat) versus 50 or $100 \%$ fluid replacement to offset body mass loss [134]. Additionally, these participants demonstrated accentuated increases in vascular resistance and plasma [norepinephrine], suggesting greater activation of the sympathetic nervous system during exercise in the hypohydrated state necessary to compensate for reductions in blood volume and pressure to maintain adequate skeletal muscle perfusion [5]. Recently, we sought to determine whether mild hypohydration affects sympathetic and BP responses during exercise pressor reflex activation. We found that very mild hypohydration ( $\sim .5 \%$ body mass loss) did not affect MSNA or BP responses during static handgrip exercise in healthy young male and female adults [212]. While the observed changes in body mass were modest following voluntary reductions in water intake over three days concluded with a 16-hour water abstention period, key considerations in our study design were to elicit increases in serum $\left[\mathrm{Na}^{+}\right]$ and determine the resultant alterations in exercise pressor reflex function. Additionally, this study design allowed for a hypohydration stimulus in the absence of exercise, heat, and diuretic usage. It is 
possible that a combination of methods is required to produce more severe hypohydration and elicit alterations in exercise pressor reflex function.

\section{Cardiovascular Regulation and Body Water Balance During Hypobaric Hypoxia}

Acute hypobaric hypoxia (i.e., high-altitude) increases BP [213] and alters body water balance via fluid shifts and changes in hormonal control of body fluid and electrolytes [214-216]. The increases in BP during acute exposure to altitude is thought to occur through endothlin-1-mediated increases in heart rate and systemic sympathetic activation. With chronic altitude exposure, there is potential to develop chronic arterial and pulmonary hypertension, the mechanisms and evidence for which are discussed in depth by Riley et al. [213]. Specific to changes in body water balance, acute altitude exposure ( $3500 \mathrm{~m}$ for 12 days) elicits reductions in extracellular water and total body water [214]. In agreement with this observation, another study reported that during the first three days at an elevation of $5334 \mathrm{~m}$, plasma volume and total body water were reduced, while plasma renin activity and serum [aldosterone] increased. As expected with these observations, sodium and potassium excretion were concomitantly reduced [216]. The findings from these previous studies are consistent with other work that demonstrated dehydration upon arrival to $4850 \mathrm{~m}$ was induced by fluid shifts to the interstitial space and produced rapid hemoconcentration (i.e., increases in hemoglobin concentrations and hematocrit values). The authors speculated that any further hemoconcentration observed during the climb from $4850 \mathrm{~m}$ to $7600 \mathrm{~m}$ can be partially explained by stimulated erythropoiesis [215]. To summarize, acute hypobaric hypoxia elicits alterations in body water balance that produce unfavorable conditions for optimal physiological function. While extended discussion on strategies to mitigate the deleterious effects of altitude on physiological function is beyond the scope of this review article, the authors suggest a review [85] by Sawka and colleagues for more information on this topic.

\section{Summary}

Hypohydration is known to reduce mental and physical performance, and more recent evidence suggests hypohydration also impairs vascular function and cardiovascular regulation. Specifically, hypohydration has been demonstrated to impair cutaneous vascular function, reduce endothelial function, and alter BP regulation at rest during exercise and during orthostatic stress (Figure 1). Future studies examining the physiological effects of hypohydration in healthy female adults are warranted as most of the previous work has been completed within male adults. Additionally, studies determining the acute and chronic effects of hypohydration in preclinical populations, such as old adults and those with hypertension, are warranted.

\section{Perspectives}

Previous literature indicates that mild hypohydration impairs cognitive function, aerobic exercise performance, and thermoregulation. Here, we highlighted the negative implications of hypohydration on vascular function and cardiovascular regulation at rest and during various perturbations (e.g., orthostatic stress, exercise). While there is less consensus regarding more mild forms of hypohydration on these cardiovascular measures, there is strong evidence that mild-to-moderate hypohydration impairs several indices of cardiovascular function. Taken together, these studies indicate that acute reductions in water intake may negatively influence cardiovascular function in healthy young humans. These deleterious cardiovascular effects of mild hypohydration are more consistent during protocols that employ exercise, heat stress, and/or diuretic usage in addition to water restriction.

Author Contributions: J.C.W. generated and W.B.F. edited this manuscript.

Funding: This review was written while J.C.W. was supported by a University of Delaware Doctoral Fellowship and W.B.F. was supported by NIH R01 HL128388 \& HL104106.

Acknowledgments: The authors would like to thank other members of Cardiovascular Physiology Research Laboratory at the University of Delaware for their critical evaluation and feedback for this review. 
Conflicts of Interest: The authors declare no conflict of interest.

\section{References}

1. McDermott, B.P.; Anderson, S.A.; Armstrong, L.E.; Casa, D.J.; Cheuvront, S.N.; Cooper, L.; Kenney, W.L.; O'Connor, F.G.; Roberts, W.O. National Athletic Trainers' Association Position Statement: Fluid Replacement for the Physically Active. J. Athl. Train. 2017, 52, 877-895. [CrossRef] [PubMed]

2. Armstrong, L.E.; Johnson, E.C. Water Intake, Water Balance, and the Elusive Daily Water Requirement. Nutrients 2018, 10, 1928. [CrossRef] [PubMed]

3. Laitano, O.; Kalsi, K.K.; Pearson, J.; Lotlikar, M.; Reischak-Oliveira, A.; González-Alonso, J. Effects of graded exercise-induced dehydration and rehydration on circulatory markers of oxidative stress across the resting and exercising human leg. Eur. J. Appl. Physiol. 2012, 112, 1937-1944. [CrossRef] [PubMed]

4. González-Alonso, J.; Mora-Rodríguez, R.; Below, P.R.; Coyle, E.F. Dehydration markedly impairs cardiovascular function in hyperthermic endurance athletes during exercise. J. Appl. Physiol. 1997, 82, 1229-1236. [CrossRef] [PubMed]

5. González-Alonso, J.; Mora-Rodríguez, R.; Below, P.R.; Coyle, E.F. Dehydration reduces cardiac output and increases systemic and cutaneous vascular resistance during exercise. J. Appl. Physiol. 1995, 79, 1487-1496. [CrossRef] [PubMed]

6. Posch, A.M.; Luippold, A.J.; Mitchell, K.M.; Bradbury, K.E.; Kenefick, R.W.; Cheuvront, S.N.; Charkoudian, N. Sympathetic neural and hemodynamic responses to head-up tilt during iso-osmotic and hyper-osmotic hypovolemia. J. Neurophysiol. 2017, 118, 2232-2237. [CrossRef] [PubMed]

7. Armstrong, L.E.; Maresh, C.M.; Gabaree, C.V.; Hoffman, J.R.; Kavouras, S.A.; Kenefick, R.W.; Castellani, J.W.; Ahlquist, L.E. Thermal and circulatory responses during exercise: Effects of hypohydration, dehydration, and water intake. J. Appl. Physiol. 1997, 82, 2028-2035. [CrossRef] [PubMed]

8. Shore, A.C.; Markandu, N.D.; Sagnella, G.A.; Singer, D.R.; Forsling, M.L.; Buckley, M.G.; Sugden, A.L.; MacGregor, G.A. Endocrine and renal response to water loading and water restriction in normal man. Clin. Sci. 1988, 75, 171-177. [CrossRef]

9. Black, D.A.; McCance, R.A.; Young, W.F. A study of dehydration by means of balance experiments. J. Physiol. 1944, 102, 406-414. [CrossRef]

10. Adams, J.D.; Sekiguchi, Y.; Suh, H.; Seal, A.D.; Sprong, C.A.; Kirkland, T.W.; Kavouras, S.A. Dehydration Impairs Cycling Performance, Independently of Thirst: A Blinded Study. Med. Sci. Sports Exerc. 2018. [CrossRef]

11. Johnson, E.C.; Bardis, C.N.; Jansen, L.T.; Adams, J.D.; Kirkland, T.W.; Kavouras, S.A. Reduced water intake deteriorates glucose regulation in patients with type 2 diabetes. Nutr. Res. 2017, 43, 25-32. [CrossRef]

12. Ganio, M.S.; Wingo, J.E.; Carrolll, C.E.; Thomas, M.K.; Cureton, K.J. Fluid ingestion attenuates the decline in VO2peak associated with cardiovascular drift. Med. Sci. Sports Exerc. 2006, 38, 901-909. [CrossRef]

13. James, L.J.; Moss, J.; Henry, J.; Papadopoulou, C.; Mears, S.A. Hypohydration impairs endurance performance: A blinded study. Physiol. Rep. 2017, 5. [CrossRef]

14. Nadel, E.R.; Fortney, S.M.; Wenger, C.B. Effect of hydration state of circulatory and thermal regulations. J. Appl. Physiol. Respir. Environ. Exerc. Physiol. 1980, 49, 715-721. [CrossRef]

15. Mack, G.W.; Weseman, C.A.; Langhans, G.W.; Scherzer, H.; Gillen, C.M.; Nadel, E.R. Body fluid balance in dehydrated healthy older men: Thirst and renal osmoregulation. J. Appl. Physiol. 1994, 76, 1615-1623. [CrossRef]

16. Fortney, S.M.; Wenger, C.B.; Bove, J.R.; Nadel, E.R. Effect of hyperosmolality on control of blood flow and sweating. J. Appl. Physiol. Respir. Environ. Exerc. Physiol. 1984, 57, 1688-1695. [CrossRef]

17. Stachenfeld, N.S.; DiPietro, L.; Nadel, E.R.; Mack, G.W. Mechanism of attenuated thirst in aging: Role of central volume receptors. Am. J. Physiol. 1997, 272, 148. [CrossRef]

18. Armstrong, L.E.; Ganio, M.S.; Casa, D.J.; Lee, E.C.; McDermott, B.P.; Klau, J.F.; Jimenez, L.; Le Bellego, L.; Chevillotte, E.; Lieberman, H.R. Mild dehydration affects mood in healthy young women. J. Nutr. 2012, 142, 382-388. [CrossRef]

19. Stachenfeld, N.S.; Leone, C.A.; Mitchell, E.S.; Freese, E.; Harkness, L. Water intake reverses dehydration associated impaired executive function in healthy young women. Physiol. Behav. 2017, 185, 103-111. [CrossRef] 
20. Faraco, G.; Wijasa, T.S.; Park, L.; Moore, J.; Anrather, J.; Iadecola, C. Water deprivation induces neurovascular and cognitive dysfunction through vasopressin-induced oxidative stress. J. Cereb. Blood Flow Metab. 2014, 34, 852-860. [CrossRef]

21. Patsalos, O.C.; Thoma, V. Water supplementation after dehydration improves judgment and decision-making performance. Psychol. Res. 2019. [CrossRef]

22. Kenney, W.L.; Tankersley, C.G.; Newswanger, D.L.; Hyde, D.E.; Puhl, S.M.; Turner, N.L. Age and hypohydration independently influence the peripheral vascular response to heat stress. J. Appl. Physiol. 1990, 68, 1902-1908. [CrossRef]

23. Fujii, N.; Honda, Y.; Hayashi, K.; Kondo, N.; Nishiyasu, T. Effect of hypohydration on hyperthermic hyperpnea and cutaneous vasodilation during exercise in men. J. Appl. Physiol. 2008, 105, 1509-1518. [CrossRef]

24. McNeely, B.D.; Meade, R.D.; Fujii, N.; Seely, A.J.E.; Sigal, R.J.; Kenny, G.P. Fluid replacement modulates oxidative stress- but not nitric oxide-mediated cutaneous vasodilation and sweating during prolonged exercise in the heat. Am. J. Physiol. Regul. Integr. Comp. Physiol. 2017, 313, R739. [CrossRef]

25. Tucker, M.A.; Six, A.; Moyen, N.E.; Satterfield, A.Z.; Ganio, M.S. Effect of hypohydration on postsynaptic cutaneous vasodilation and sweating in healthy men. Am. J. Physiol. Regul. Integr. Comp. Physiol. 2017, 312, R642. [CrossRef]

26. Caldwell, A.R.; Tucker, M.A.; Burchfield, J.; Moyen, N.E.; Satterfield, A.Z.; Six, A.; McDermott, B.P.; Mulvenon, S.W.; Ganio, M.S. Hydration status influences the measurement of arterial stiffness. Clin. Physiol. Funct. Imaging. 2018, 38, 447-454. [CrossRef]

27. Arnaoutis, G.; Kavouras, S.A.; Stratakis, N.; Likka, M.; Mitrakou, A.; Papamichael, C.; Sidossis, L.S.; Stamatelopoulos, K. The effect of hypohydration on endothelial function in young healthy adults. Eur. J. Nutr. 2017, 56, 1211-1217. [CrossRef]

28. Rabbitts, J.A.; Strom, N.A.; Sawyer, J.R.; Curry, T.B.; Dietz, N.M.; Roberts, S.K.; Kingsley-Berg, S.M.; Charkoudian, N. Influence of endogenous angiotensin II on control of sympathetic nerve activity in human dehydration. J. Physiol. 2009, 587, 5441-5449. [CrossRef]

29. Kimmerly, D.S.; Shoemaker, J.K. Hypovolemia and neurovascular control during orthostatic stress. Am. J. Physiol. Heart Circ. Physiol. 2002, 282, 645. [CrossRef]

30. Harrison, M.H.; Geelen, G.; Keil, L.C.; Wade, C.A.; Hill, L.C.; Kravik, S.E.; Greenleaf, J.E. Effect of hydration on plasma vasopressin, renin, and aldosterone responses to head-up tilt. Aviat. Space Environ. Med. 1986, 57, 420-425.

31. Trangmar, S.J.; Chiesa, S.T.; Stock, C.G.; Kalsi, K.K.; Secher, N.H.; González-Alonso, J. Dehydration affects cerebral blood flow but not its metabolic rate for oxygen during maximal exercise in trained humans. J. Physiol. 2014, 592, 3143-3160. [CrossRef]

32. Freeman, K.L.; Brooks, V.L. AT(1) and glutamatergic receptors in paraventricular nucleus support blood pressure during water deprivation. Am. J. Physiol. Regul. Integr. Comp. Physiol. 2007, 292, 1675. [CrossRef]

33. Phillips, P.A.; Rolls, B.J.; Ledingham, J.G.; Forsling, M.L.; Morton, J.J.; Crowe, M.J.; Wollner, L. Reduced thirst after water deprivation in healthy elderly men. N Engl. J. Med. 1984, 311, 753-759. [CrossRef]

34. Szinnai, G.; Morgenthaler, N.G.; Berneis, K.; Struck, J.; Müller, B.; Keller, U.; Christ-Crain, M. Changes in plasma copeptin, the c-terminal portion of arginine vasopressin during water deprivation and excess in healthy subjects. J. Clin. Endocrinol. Metab. 2007, 92, 3973-3978. [CrossRef]

35. Gregory, L.C.; Quillen, E.W.; Keil, L.C.; Chang, D.; Reid, I.A. Effect of vasopressin blockade on blood pressure during water deprivation in intact and baroreceptor-denervated conscious dogs. Am. J. Physiol. 1988, 254, 490. [CrossRef]

36. Schwartz, J.; Reid, I.A. Role of vasopressin in blood pressure regulation in conscious water-deprived dogs. Am. J. Physiol. 1983, 244, 74. [CrossRef]

37. Blair, M.L.; Woolf, P.D.; Felten, S.Y. Sympathetic activation cannot fully account for increased plasma renin levels during water deprivation. Am. J. Physiol. 1997, 272, 1197. [CrossRef]

38. Brooks, V.L.; Keil, L.C. Vasopressin and angiotensin II in reflex regulation of ACTH, glucocorticoids, and renin: Effect of water deprivation. Am. J. Physiol. 1992, 263, 762. [CrossRef]

39. Brooks, V.L.; Huhtala, T.A.; Silliman, T.L.; Engeland, W.C. Water deprivation and rat adrenal mRNAs for tyrosine hydroxylase and the norepinephrine transporter. Am. J. Physiol. 1997, 272, 1897. [CrossRef] 
40. Aisenbrey, G.A.; Handelman, W.A.; Arnold, P.; Manning, M.; Schrier, R.W. Vascular effects of arginine vasopressin during fluid deprivation in the rat. J. Clin. Invest. 1981, 67, 961-968. [CrossRef]

41. Kinsman, B.J.; Browning, K.N.; Stocker, S.D. NaCl and osmolarity produce different responses in organum vasculosum of the lamina terminalis neurons, sympathetic nerve activity and blood pressure. J. Physiol. 2017, 595, 6187-6201. [CrossRef]

42. Duvernoy, H.M.; Risold, P. The circumventricular organs: An atlas of comparative anatomy and vascularization. Brain Res. Rev. 2007, 56, 119-147. [CrossRef]

43. Danziger, J.; Zeidel, M.L. Osmotic homeostasis. Clin. J. Am. Soc. Nephrol. 2015, 10, 852-862. [CrossRef]

44. Nomura, K.; Hiyama, T.Y.; Sakuta, H.; Matsuda, T.; Lin, C.; Kobayashi, K.; Kobayashi, K.; Kuwaki, T.; Takahashi, K.; Matsui, S.; et al. [Na+] Increases in Body Fluids Sensed by Central Nax Induce Sympathetically Mediated Blood Pressure Elevations via H+-Dependent Activation of ASIC1a. Neuron 2019, 101, 75. [CrossRef]

45. Leib, D.E.; Zimmerman, C.A.; Poormoghaddam, A.; Huey, E.L.; Ahn, J.S.; Lin, Y.; Tan, C.L.; Chen, Y.; Knight, Z.A. The Forebrain Thirst Circuit Drives Drinking through Negative Reinforcement. Neuron 2017, 96, 1281. [CrossRef]

46. Lowell, B.B. New Neuroscience of Homeostasis and Drives for Food, Water, and Salt. N Engl. J. Med. 2019, 380, 459-471. [CrossRef]

47. Deen, P.M.; Verdijk, M.A.; Knoers, N.V.; Wieringa, B.; Monnens, L.A.; van Os, C.H.; van Oost, B.A. Requirement of human renal water channel aquaporin-2 for vasopressin-dependent concentration of urine. Science 1994, 264, 92-95. [CrossRef]

48. Owen, J.A.; Fortes, M.B.; Rahman, S.U.; Jibani, M.; Walsh, N.P.; Oliver, S.J. Hydration Marker Diagnostic Accuracy to Identify Mild Intracellular and Extracellular Dehydration. Int. J. Sport Nutr. Exerc. Metab. 2019, 1-23. [CrossRef]

49. Van Zwalenburg, C. Dehydration in Heat Exhaustion and in Fatigue. Cal. West. Med. 1933, 38, $354-358$.

50. Stookey, J.D. Analysis of 2009-2012 Nutrition Health and Examination Survey (NHANES) Data to Estimate the Median Water Intake Associated with Meeting Hydration Criteria for Individuals Aged 12-80 in the US Population. Nutrients 2019, 11, 657. [CrossRef]

51. Drewnowski, A.; Rehm, C.D.; Constant, F. Water and beverage consumption among adults in the United States: Cross-sectional study using data from NHANES 2005-2010. BMC Public Health 2013, 13, 1068. [CrossRef]

52. Chang, T.; Ravi, N.; Plegue, M.A.; Sonneville, K.R.; Davis, M.M. Inadequate Hydration, BMI, and Obesity Among US Adults: NHANES 2009-2012. Ann. Fam. Med. 2016, 14, 320-324. [CrossRef]

53. Chan, J.; Knutsen, S.F.; Blix, G.G.; Lee, J.W.; Fraser, G.E. Water, other fluids, and fatal coronary heart disease: The Adventist Health Study. Am. J. Epidemiol. 2002, 155, 827-833. [CrossRef]

54. Xu, J.; Murphy, S.L.; Kochanek, K.D.; Bastian, B.; Arias, E. Deaths: Final Data for 2016. Natl. Vital Stat. Rep. 2018, 67, 1-76.

55. Lang, F.; Guelinckx, I.; Lemetais, G.; Melander, O. Two Liters a Day Keep the Doctor Away? Considerations on the Pathophysiology of Suboptimal Fluid Intake in the Common Population. Kidney Blood Pres. Res. 2017, 42, 483-494. [CrossRef]

56. Dmitrieva, N.I.; Burg, M.B. Elevated sodium and dehydration stimulate inflammatory signaling in endothelial cells and promote atherosclerosis. PLoS ONE 2015, 10, 1-22. [CrossRef]

57. Bulpitt, C.J.; Shipley, M.J.; Semmence, A. Blood pressure and plasma sodium and potassium. Clin. Sci. 1981, 61, 85s-87s. [CrossRef]

58. Komiya, I.; Yamada, T.; Takasu, N.; Asawa, T.; Akamine, H.; Yagi, N.; Nagasawa, Y.; Ohtsuka, H.; Miyahara, Y.; Sakai, H.; et al. An abnormal sodium metabolism in Japanese patients with essential hypertension, judged by serum sodium distribution, renal function and the renin-aldosterone system. J. Hypertens. 1997, 15, 65-72. [CrossRef]

59. Wannamethee, G.; Whincup, P.H.; Shaper, A.G.; Lever, A.F. Serum sodium concentration and risk of stroke in middle-aged males. J. Hypertens. 1994, 12, 971-979. [CrossRef]

60. Lago, R.M.; Pencina, M.J.; Wang, T.J.; Lanier, K.J.; D’Agostino, R.B.; Kannel, W.B.; Vasan, R.S. Interindividual variation in serum sodium and longitudinal blood pressure tracking in the Framingham Heart Study. J. Hypertens. 2008, 26, 2121-2125. [CrossRef] 
61. Stookey, J.D. High Prevalence of Plasma Hypertonicity among Community-Dwelling Older Adults: Results from NHANES III. J. Am. Diet. Assoc. 2005, 105, 1231-1239. [CrossRef]

62. Davy, K.P.; Seals, D.R. Total blood volume in healthy young and older men. J. Appl. Physiol. 1994, 76, 2059-2062. [CrossRef]

63. Phillips, P.A.; Johnston, C.I.; Gray, L. Disturbed fluid and electrolyte homoeostasis following dehydration in elderly people. Age Ageing 1993, 22, S33. [CrossRef]

64. Phillips, P.A.; Bretherton, M.; Risvanis, J.; Casley, D.; Johnston, C.; Gray, L. Effects of drinking on thirst and vasopressin in dehydrated elderly men. Am. J. Physiol. 1993, 264, 877. [CrossRef]

65. Bevilacqua, M.; Norbiato, G.; Chebat, E.; Raggi, U.; Cavaiani, P.; Guzzetti, R.; Bertora, P. Osmotic and nonosmotic control of vasopressin release in the elderly: Effect of metoclopramide. J. Clin. Endocrinol. Metab. 1987, 65, 1243-1247. [CrossRef]

66. Crowe, M.J.; Forsling, M.L.; Rolls, B.J.; Phillips, P.A.; Ledingham, J.G.; Smith, R.F. Altered water excretion in healthy elderly men. Age Ageing 1987, 16, 285-293. [CrossRef]

67. Savoie, F.; Kenefick, R.; Ely, B.; Cheuvront, S.; Goulet, E. Effect of Hypohydration on Muscle Endurance, Strength, Anaerobic Power and Capacity and Vertical Jumping Ability: A Meta-Analysis. Sports Med. 2015, 45, 1207-1227. [CrossRef]

68. Adams, W.M.; Ferraro, E.M.; Huggins, R.A.; Casa, D.J. Influence of body mass loss on changes in heart rate during exercise in the heat: A systematic review. J. Strength Cond Res. 2014, 28, 2380-2389. [CrossRef]

69. Murray, B. Hydration and Physical Performance. Am. Coll. Nutrition 2007, 26, 542S. [CrossRef]

70. Sawka, M.N.; Cheuvront, S.N.; Kenefick, R.W. High skin temperature and hypohydration impair aerobic performance. Exp. Physiol. 2012, 97, 327-332. [CrossRef]

71. Sawka, M.N.; Francesconi, R.P.; Young, A.J.; Pandolf, K.B. Influence of hydration level and body fluids on exercise performance in the heat. JAMA 1984, 252, 1165-1169. [CrossRef]

72. Sawka, M.N. Physiological consequences of hypohydration: Exercise performance and thermoregulation. Med. Sci. Sports Exerc. 1992, 24, 657-670. [CrossRef]

73. Roy, B.D.; Green, H.J.; Burnett, M.E. Prolonged exercise following diuretic-induced hypohydration: Effects on cardiovascular and thermal strain. Can. J. Physiol. Pharmacol. 2000, 78, 541-547. [CrossRef]

74. Cheung, S.S.; McLellan, T.M. Influence of short-term aerobic training and hydration status on tolerance during uncompensable heat stress. Eur. J. Appl. Physiol. Occup. Physiol. 1998, 78, 50-58. [CrossRef]

75. Hayes, L.D.; Morse, C.I. The effects of progressive dehydration on strength and power: Is there a dose response? Eur. J. Appl. Physiol. 2010, 108, 701-707. [CrossRef]

76. McLellan, T.M.; Cheung, S.S.; Latzka, W.A.; Sawka, M.N.; Pandolf, K.B.; Millard, C.E.; Withey, W.R. Effects of dehydration, hypohydration, and hyperhydration on tolerance during uncompensable heat stress. Can. J. Appl. Physiol. 1999, 24, 349-361. [CrossRef]

77. Maughan, R.J. Impact of mild dehydration on wellness and on exercise performance. Eur. J. Clin. Nutr. 2003, 57, 19. [CrossRef]

78. Cheuvront, S.N.; Carter, R.; Castellani, J.W.; Sawka, M.N. Hypohydration impairs endurance exercise performance in temperate but not cold air. J. Appl. Physiol. 2005, 99, 1972-1976. [CrossRef]

79. MacLeod, H.; Sunderland, C. Previous-day hypohydration impairs skill performance in elite female field hockey players. Scand J. Med. Sci. Sports 2012, 22, 430-438. [CrossRef]

80. Kenefick, R.W.; Cheuvront, S.N.; Palombo, L.J.; Ely, B.R.; Sawka, M.N. Skin temperature modifies the impact of hypohydration on aerobic performance. J. Appl. Physiol. 2010, 109, 79-86. [CrossRef]

81. Montain, S.J.; Sawka, M.N.; Latzka, W.A.; Valeri, C.R. Thermal and cardiovascular strain from hypohydration: Influence of exercise intensity. Int. J. Sports Med. 1998, 19, 87-91. [CrossRef]

82. Merry, T.L.; Ainslie, P.N.; Cotter, J.D. Effects of aerobic fitness on hypohydration-induced physiological strain and exercise impairment. Acta Physiol. 2010, 198, 179-190. [CrossRef]

83. Bardis, C.N.; Kavouras, S.A.; Arnaoutis, G.; Panagiotakos, D.B.; Sidossis, L.S. Mild dehydration and cycling performance during 5-kilometer hill climbing. J. Athl. Train. 2013, 48, 741-747. [CrossRef]

84. Bardis, C.N.; Kavouras, S.A.; Kosti, L.; Markousi, M.; Sidossis, L.S. Mild hypohydration decreases cycling performance in the heat. Med. Sci. Sports Exerc. 2013, 45, 1782-1789. [CrossRef]

85. Sawka, M.N.; Cheuvront, S.N.; Kenefick, R.W. Hypohydration and Human Performance: Impact of Environment and Physiological Mechanisms. Sports Med. 2015, 45, 51. [CrossRef] 
86. Judelson, D.A.; Maresh, C.M.; Farrell, M.J.; Yamamoto, L.M.; Armstrong, L.E.; Kraemer, W.J.; Volek, J.S.; Spiering, B.A.; Casa, D.J.; Anderson, J.M. Effect of hydration state on strength, power, and resistance exercise performance. Med. Sci. Sports Exerc. 2007, 39, 1817-1824. [CrossRef]

87. Tan, X.R.; Low, I.C.C.; Stephenson, M.C.; Kok, T.; Nolte, H.W.; Soong, T.W.; Lee, J.K.W. Altered Brain Structure with Preserved Cortical Motor Activity Following Exertional Hypohydration: A MRI study. J. Appl. Physiol. 2019. [CrossRef]

88. Gamble, A.S.; Bigg, J.L.; Vermeulen, T.F.; Boville, S.M.; Eskedjian, G.S.; Jannas-Vela, S.; Whitfield, J.; Palmer, M.S.; Spriet, L.L. Estimated Sweat Loss, Fluid and CHO Intake, and Sodium Balance of Male Major Junior, AHL, and NHL Players During On-Ice Practices. Int. J. Sport Nutr. Exerc. Metab. 2019, 1-25. [CrossRef]

89. Ely, B.R.; Sollanek, K.J.; Cheuvront, S.N.; Lieberman, H.R.; Kenefick, R.W. Hypohydration and acute thermal stress affect mood state but not cognition or dynamic postural balance. Eur. J. Appl. Physiol. 2013, 113, 1027-1034. [CrossRef]

90. Moyen, N.E.; Ganio, M.S.; Wiersma, L.D.; Kavouras, S.A.; Gray, M.; McDermott, B.P.; Adams, J.D.; Binns, A.P.; Judelson, D.A.; McKenzie, A.L.; et al. Hydration status affects mood state and pain sensation during ultra-endurance cycling. J. Sports Sci. 2015, 33, 1962-1969. [CrossRef]

91. Zhang, N.; Du, S.M.; Zhang, J.F.; Ma, G.S. Effects of Dehydration and Rehydration on Cognitive Performance and Mood among Male College Students in Cangzhou, China: A Self-Controlled Trial. Int. J. Environ. Res. Public Health 2019, 16, 1891. [CrossRef]

92. Benton, D.; Jenkins, K.T.; Watkins, H.T.; Young, H.A. Minor degree of hypohydration adversely influences cognition: A mediator analysis. Am. J. Clin. Nutr. 2016, 104, 603-612. [CrossRef]

93. Greenleaf, J.E.; Castle, B.L. Exercise temperature regulation in man during hypohydration and hyperhydration. J. Appl. Physiol. 1971, 30, 847-853. [CrossRef]

94. Candas, V.; Libert, J.P.; Brandenberger, G.; Sagot, J.C.; Kahn, J.M. Thermal and circulatory responses during prolonged exercise at different levels of hydration. J. Physiol. (Paris) 1988, 83, 11-18.

95. Cadarette, B.S.; Sawka, M.N.; Toner, M.M.; Pandolf, K.B. Aerobic fitness and the hypohydration response to exercise-heat stress. Aviat. Space Environ. Med. 1984, 55, 507-512.

96. Sawka, M.N.; Gonzalez, R.R.; Young, A.J.; Muza, S.R.; Pandolf, K.B.; Latzka, W.A.; Dennis, R.C.; Valeri, C.R. Polycythemia and hydration: Effects on thermoregulation and blood volume during exercise-heat stress. Am. J. Physiol. 1988, 255, 456. [CrossRef]

97. Montain, S.J.; Latzka, W.A.; Sawka, M.N. Control of thermoregulatory sweating is altered by hydration level and exercise intensity. J. Appl. Physiol. 1995, 79, 1434-1439. [CrossRef]

98. Buono, M.J.; Wall, A.J. Effect of hypohydration on core temperature during exercise in temperate and hot environments. Eur. J. Physiol. 2000, 440, 476-480. [CrossRef]

99. Meade, R.D.; Notley, S.R.; D'Souza, A.W.; Dervis, S.; Boulay, P.; Sigal, R.J.; Kenny, G.P. Interactive effects of age and hydration state on human thermoregulatory function during exercise in hot-dry conditions. Acta Physiol. 2018, e13226. [CrossRef]

100. Kenefick, R.W.; Sollanek, K.J.; Charkoudian, N.; Sawka, M.N. Impact of skin temperature and hydration on plasma volume responses during exercise. J. Appl. Physiol. 2014, 117, 413-420. [CrossRef]

101. Raines, J.; Snow, R.; Nichols, D.; Aisbett, B. Fluid intake, hydration, work physiology of wildfire fighters working in the heat over consecutive days. Ann. Occup. Hyg. 2015, 59, 554-565.

102. Horowitz, M.; Kaspler, P.; Simon, E.; Gerstberger, R. Heat acclimation and hypohydration: Involvement of central angiotensin II receptors in thermoregulation. Am. J. Physiol. 1999, 277, 47. [CrossRef]

103. Sawka, M.N.; Latzka, W.A.; Matott, R.P.; Montain, S.J. Hydration effects on temperature regulation. Int. J. Sports Med. 1998, 19, 108. [CrossRef]

104. Sawka, M.N.; Young, A.J.; Francesconi, R.P.; Muza, S.R.; Pandolf, K.B. Thermoregulatory and blood responses during exercise at graded hypohydration levels. J. Appl. Physiol. 1985, 59, 1394-1401. [CrossRef]

105. Moyen, N.E.; Burchfield, J.M.; Butts, C.L.; Glenn, J.M.; Tucker, M.A.; Treece, K.; Smith, A.J.; McDermott, B.P.; Ganio, M.S. Effects of obesity and mild hypohydration on local sweating and cutaneous vascular responses during passive heat stress in females. Appl. Physiol. Nutr. Metab. 2016, 41, 879-887. [CrossRef]

106. Tokizawa, K.; Yasuhara, S.; Nakamura, M.; Uchida, Y.; Crawshaw, L.I.; Nagashima, K. Mild hypohydration induced by exercise in the heat attenuates autonomic thermoregulatory responses to the heat, but not thermal pleasantness in humans. Physiol. Behav. 2010, 100, 340-345. [CrossRef] 
107. Ikegawa, S.; Kamijo, Y.; Okazaki, K.; Masuki, S.; Okada, Y.; Nose, H. Effects of hypohydration on thermoregulation during exercise before and after 5-day aerobic training in a warm environment in young men. J. Appl. Physiol. 2011, 110, 972-980. [CrossRef]

108. Tucker, M.A.; Caldwell, A.R.; Butts, C.L.; Robinson, F.B.; Reynebeau, H.C.; Kavouras, S.A.; McDermott, B.P.; Washington, T.A.; Turner, R.C.; Ganio, M.S. Effect of hypohydration on thermoregulatory responses in men with low and high body fat exercising in the heat. J. Appl. Physiol. 2017, 122, 142-152. [CrossRef]

109. Roussel, R.; Fezeu, L.; Bouby, N.; Balkau, B.; Lantieri, O.; Alhenc-Gelas, F.; Marre, M.; Bankir, L. Low water intake and risk for new-onset hyperglycemia. Diabetes Care 2011, 34, 2551-2554. [CrossRef]

110. Manz, F. Hydration and Disease. J. Am. Coll Nutr. 2007, 26, 541S. [CrossRef]

111. Yeboah, J.; Folsom, A.R.; Burke, G.L.; Johnson, C.; Polak, J.F.; Post, W.; Lima, J.A.; Crouse, J.R.; Herrington, D.M. Predictive value of brachial flow-mediated dilation for incident cardiovascular events in a population-based study: The multi-ethnic study of atherosclerosis. Circulation 2009, 120, 502-509. [CrossRef]

112. Yeboah, J.; Crouse, J.R.; Hsu, F.; Burke, G.L.; Herrington, D.M. Brachial flow-mediated dilation predicts incident cardiovascular events in older adults: The Cardiovascular Health Study. Circulation 2007, 115, 2390-2397. [CrossRef]

113. Lind, L.; Berglund, L.; Larsson, A.; Sundström, J. Endothelial function in resistance and conduit arteries and 5-year risk of cardiovascular disease. Circulation 2011, 123, 1545-1551. [CrossRef]

114. Widlansky, M.E.; Gokce, N.; Keaney, J.F.; Vita, J.A. The clinical implications of endothelial dysfunction. J. Am. Coll. Cardiol. 2003, 42, 1149-1160. [CrossRef]

115. Benjamin, E.J.; Muntner, P.; Alonso, A.; Bittencourt, M.S.; Callaway, C.W.; Carson, A.P.; Chamberlain, A.M.; Chang, A.R.; Cheng, S.; Das, S.R.; et al. Heart Disease and Stroke Statistics-2019 Update: A Report From the American Heart Association. Circulation 2019, 139, e56-e528. [CrossRef]

116. Parati, G.; Pomidossi, G.; Albini, F.; Malaspina, D.; Mancia, G. Relationship of 24-hour blood pressure mean and variability to severity of target-organ damage in hypertension. J. Hypertens. 1987, 5, 93-98. [CrossRef]

117. Tatasciore, A.; Renda, G.; Zimarino, M.; Soccio, M.; Bilo, G.; Parati, G.; Schillaci, G.; De Caterina, R. Awake systolic blood pressure variability correlates with target-organ damage in hypertensive subjects. Hypertension 2007, 50, 325-332. [CrossRef]

118. Veloudi, P.; Blizzard, C.L.; Head, G.A.; Abhayaratna, W.P.; Stowasser, M.; Sharman, J.E. Blood Pressure Variability and Prediction of Target Organ Damage in Patients with Uncomplicated Hypertension. Am. J. Hypertens 2016, 29, 1046-1054. [CrossRef]

119. Mancia, G.; Bombelli, M.; Facchetti, R.; Madotto, F.; Corrao, G.; Trevano, F.Q.; Grassi, G.; Sega, R. Long-term prognostic value of blood pressure variability in the general population: Results of the Pressioni Arteriose Monitorate e Loro Associazioni Study. Hypertension 2007, 49, 1265-1270. [CrossRef]

120. Pringle, E.; Phillips, C.; Thijs, L.; Davidson, C.; Staessen, J.A.; de Leeuw, P.W.; Jaaskivi, M.; Nachev, C.; Parati, G.; O'Brien, E.T.; et al. Systolic blood pressure variability as a risk factor for stroke and cardiovascular mortality in the elderly hypertensive population. J. Hypertens. 2003, 21, 2251-2257. [CrossRef]

121. Fleg, J.L.; Evans, G.W.; Margolis, K.L.; Barzilay, J.; Basile, J.N.; Bigger, J.T.; Cutler, J.A.; Grimm, R.; Pedley, C.; Peterson, K.; et al. Orthostatic Hypotension in the ACCORD (Action to Control Cardiovascular Risk in Diabetes) Blood Pressure Trial: Prevalence, Incidence, and Prognostic Significance. Hypertension 2016, 68, 888-895. [CrossRef]

122. Veronese, N.; De Rui, M.; Bolzetta, F.; Zambon, S.; Corti, M.C.; Baggio, G.; Toffanello, E.D.; Maggi, S.; Crepaldi, G.; Perissinotto, E.; et al. Orthostatic Changes in Blood Pressure and Mortality in the Elderly: The Pro.V.A Study. Am. J. Hypertens. 2015, 28, 1248-1256. [CrossRef]

123. Tzemos, N.; Lim, P.O.; Mackenzie, I.S.; MacDonald, T.M. Exaggerated Exercise Blood Pressure Response and Future Cardiovascular Disease. J. Clin. Hyper. 2015, 17, 837-844. [CrossRef]

124. Miyai, N.; Arita, M.; Miyashita, K.; Morioka, I.; Shiraishi, T.; Nishio, I. Blood pressure response to heart rate during exercise test and risk of future hypertension. Hypertension 2002, 39, 761-766. [CrossRef]

125. Matthews, K.A.; Woodall, K.L.; Allen, M.T. Cardiovascular reactivity to stress predicts future blood pressure status. Hypertension 1993, 22, 479-485. [CrossRef]

126. Schultz, M.G.; Otahal, P.; Picone, D.S.; Sharman, J.E. Clinical Relevance of Exaggerated Exercise Blood Pressure. J. Am. Coll. Cardiol. 2015, 66, 1843-1845. [CrossRef] 
127. Côté, C.E.; Rhéaume, C.; Poirier, P.; Després, J.P.; Alméras, N. Deteriorated Cardiometabolic Risk Profile in Individuals with Excessive Blood Pressure Response to Submaximal Exercise. Am. J. Hypertens. 2019. [CrossRef]

128. Costa, R.J.S.; Camoes-Costa, V.; Snipe, R.M.J.; Dixon, D.; Russo, I.; Huschtscha, Z. The impact of exercise-induced hypohydration on gastrointestinal integrity, function, symptoms, and systemic endotoxin and inflammatory profile. J. Appl. Physiol. 2019. [CrossRef]

129. Martin, J.V.; Liberati, D.M.; Diebel, L.N. Excess sodium is deleterious on endothelial and glycocalyx barrier function: A microfluidic study. J. Trauma Acute Care Surg. 2018, 85, 128-134. [CrossRef]

130. Tremblay, J.C.; Hoiland, R.L.; Howe, C.A.; Coombs, G.B.; Vizcardo-Galindo, G.A.; Figueroa-Mujíca, R.J.; Bermudez, D.; Gibbons, T.D.; Stacey, B.S.; Bailey, D.M.; et al. Global REACH 2018: High Blood Viscosity and Hemoglobin Concentration Contribute to Reduced Flow-Mediated Dilation in High-Altitude Excessive Erythrocytosis. Hypertension 2019, 73, 1327-1335. [CrossRef]

131. Parkhurst, K.L.; Lin, H.; Devan, A.E.; Barnes, J.N.; Tarumi, T.; Tanaka, H. Contribution of blood viscosity in the assessment of flow-mediated dilation and arterial stiffness. Vasc. Med. 2012, 17, 231-234. [CrossRef]

132. Rognmo, O.; Bjørnstad, T.H.; Kahrs, C.; Tjønna, A.E.; Bye, A.; Haram, P.M.; Stølen, T.; Slørdahl, S.A.; Wisløff, U. Endothelial function in highly endurance-trained men: Effects of acute exercise. J. Strength Cond. Res. 2008, 22, 535-542. [CrossRef]

133. Vlachopoulos, C.; Aznaouridis, K.; Stefanadis, C. Prediction of cardiovascular events and all-cause mortality with arterial stiffness: A systematic review and meta-analysis. J. Am. Coll. Cardiol. 2010, 55, 1318-1327. [CrossRef]

134. McConell, G.K.; Burge, C.M.; Skinner, S.L.; Hargreaves, M. Influence of ingested fluid volume on physiological responses during prolonged exercise. Acta Physiol. Scand. 1997, 160, 149-156. [CrossRef]

135. Brake, D.J.; Bates, G.P. Fluid losses and hydration status of industrial workers under thermal stress working extended shifts. Occup. Environ. Med. 2003, 60, 90-96. [CrossRef]

136. Senay, L.C. Temperature regulation and hypohydration: A singular view. J. Appl. Physiol. Respir. Environ. Exerc. Physiol. 1979, 47, 1-7. [CrossRef]

137. Sawka, M.N.; Montain, S.J.; Latzka, W.A. Hydration effects on thermoregulation and performance in the heat. Comp. Biochem. Physiol. Part. A Mol. Integr. Physiol. 2001, 128, 679-690. [CrossRef]

138. Kenefick, R.W.; Cheuvront, S.N. Physiological adjustments to hypohydration: Impact on thermoregulation. Auton. Neurosci. 2016, 196, 47-51. [CrossRef]

139. Hall, J.E. Guyton and Hall Textbook of Medical Physiology, 13th ed.; Elsevier: Amsterdam, The Nederland, 2016.

140. Endemann, D.H.; Schiffrin, E.L. Endothelial dysfunction. J. Am. Soc. Nephrol. 2004, 15, 1983-1992. [CrossRef]

141. Diep, Q.N.; Amiri, F.; Touyz, R.M.; Cohn, J.S.; Endemann, D.; Neves, M.F.; Schiffrin, E.L. PPARalpha activator effects on Ang II-induced vascular oxidative stress and inflammation. Hypertension 2002, 40, 866-871. [CrossRef]

142. Diep, Q.N.; El Mabrouk, M.; Cohn, J.S.; Endemann, D.; Amiri, F.; Virdis, A.; Neves, M.F.; Schiffrin, E.L. Structure, endothelial function, cell growth, and inflammation in blood vessels of angiotensin II-infused rats: Role of peroxisome proliferator-activated receptor-gamma. Circulation 2002, 105, 2296-2302. [CrossRef]

143. Rajagopalan, S.; Kurz, S.; Münzel, T.; Tarpey, M.; Freeman, B.A.; Griendling, K.K.; Harrison, D.G. Angiotensin II-mediated hypertension in the rat increases vascular superoxide production via membrane NADH/NADPH oxidase activation. Contribution to alterations of vasomotor tone. J. Clin. Invest. 1996, 97, 1916-1923. [CrossRef]

144. Robinson, A.T.; Fancher, I.S.; Sudhahar, V.; Bian, J.T.; Cook, M.D.; Mahmoud, A.M.; Ali, M.M.; Ushio-Fukai, M.; Brown, M.D.; Fukai, T.; et al. Short-term regular aerobic exercise reduces oxidative stress produced by acute in the adipose microvasculature. Am. J. Physiol. Heart Circ. Physiol. 2017, 312, H906. [CrossRef]

145. Touyz, R.M.; Schiffrin, E.L. Ang II-stimulated superoxide production is mediated via phospholipase D in human vascular smooth muscle cells. Hypertension 1999, 34, 976-982. [CrossRef]

146. Touyz, R.M.; Chen, X.; Tabet, F.; Yao, G.; He, G.; Quinn, M.T.; Pagano, P.J.; Schiffrin, E.L. Expression of a functionally active gp91phox-containing neutrophil-type $\mathrm{NAD}(\mathrm{P}) \mathrm{H}$ oxidase in smooth muscle cells from human resistance arteries: Regulation by angiotensin II. Circ. Res. 2002, 90, 1205-1213. [CrossRef]

147. Schwimmer, H.; Gerstberger, R.; Horowitz, M. Nitric oxide and angiotensin II: Neuromodulation of thermoregulation during combined heat and hypohydration stress. Brain Res. 2004, 1006, 177-189. [CrossRef] 
148. Koh, K.K.; Ahn, J.Y.; Han, S.H.; Kim, D.S.; Jin, D.K.; Kim, H.S.; Shin, M.; Ahn, T.H.; Choi, I.S.; Shin, E.K. Pleiotropic effects of angiotensin II receptor blocker in hypertensive patients. J. Am. Coll. Cardiol. 2003, 42, 905-910. [CrossRef]

149. Willemsen, J.M.; Westerink, J.W.; Dallinga-Thie, G.M.; van Zonneveld, A.; Gaillard, C.A.; Rabelink, T.J.; de Koning Eelco, J.P. Angiotensin II type 1 receptor blockade improves hyperglycemia-induced endothelial dysfunction and reduces proinflammatory cytokine release from leukocytes. J. Cardiovasc. Pharmacol. 2007, 49, 6-12. [CrossRef]

150. Preumont, N.; Unger, P.; Goldman, S.; Berkenboom, G. Effect of long-term angiotensin II type I receptor antagonism on peripheral and coronary vasomotion. Cardiovasc. Drugs Ther. 2004, 18, 197-202. [CrossRef]

151. Bellien, J.; Iacob, M.; Eltchaninoff, H.; Bourkaib, R.; Thuillez, C.; Joannides, R. AT1 receptor blockade prevents the decrease in conduit artery flow-mediated dilatation during NOS inhibition in humans. Clin. Sci. 2007, 112, 393-401. [CrossRef]

152. Warnholtz, A.; Ostad, M.A.; Heitzer, T.; Thuneke, F.; Fröhlich, M.; Tschentscher, P.; Schwedhelm, E.; Böger, R.; Meinertz, T.; Munzel, T. AT1-receptor blockade with irbesartan improves peripheral but not coronary endothelial dysfunction in patients with stable coronary artery disease. Atherosclerosis 2007, 194, 439-445. [CrossRef]

153. Watanabe, Y.; Kikuchi, T.; Mitsuhashi, T.; Kimura, H.; Tsuchida, Y.; Otsuka, K. Administration of angiotensin receptor II blockade improves vascular function, urinary albumin excretion, and left ventricular hypertrophy in low-risk essential hypertensive patients receiving antihypertensive treatment with calcium channel blockers. Clin. Exp. Hypertens. 2013, 35, 87-94. [CrossRef]

154. Mizuno, Y.; Jacob, R.F.; Mason, R.P. Effects of calcium channel and renin-angiotensin system blockade on intravascular and neurohormonal mechanisms of hypertensive vascular disease. Am. J. Hypertens. 2008, 21, 1076-1085. [CrossRef]

155. Płonowski, A.; Szymańska-Debińska, T.; Radzikowska, M.; Baranowska, B.; Woźniewicz, B. Are mu-opioid receptors involved in the control of endothelin-1 release from the pituitary gland in normal and dehydrated rats? Regul. Pept. 1997, 69, 89-94. [CrossRef]

156. Maeda, S.; Miyauchi, T.; Waku, T.; Koda, Y.; Kono, I.; Goto, K.; Matsuda, M. Plasma endothelin-1 level in athletes after exercise in a hot environment: Exercise-induced dehydration contributes to increases in plasma endothelin-1. Life Sci. 1996, 58, 1259-1268. [CrossRef]

157. Bellien, J.; Iacob, M.; Monteil, C.; Rémy-Jouet, I.; Roche, C.; Duflot, T.; Vendeville, C.; Gutierrez, L.; Thuillez, C.; Richard, V.; et al. Physiological role of endothelin-1 in flow-mediated vasodilatation in humans and impact of cardiovascular risk factors. J. Hypertens 2017, 35, 1204-1212. [CrossRef]

158. Nishiyama, S.K.; Zhao, J.; Wray, D.W.; Richardson, R.S. Vascular function and endothelin-1: Tipping the balance between vasodilation and vasoconstriction. J. Appl. Physiol. 2017, 122, 354-360. [CrossRef]

159. Perry, B.G.; Bear, T.L.K.; Lucas, S.J.E.; Mündel, T. Mild dehydration modifies the cerebrovascular response to the cold pressor test. Exp. Physiol. 2016, 101, 135-142. [CrossRef]

160. Adams, J.M.; McCarthy, J.J.; Stocker, S.D. Excess dietary salt alters angiotensinergic regulation of neurons in the rostral ventrolateral medulla. Hypertension 2008, 52, 932-937. [CrossRef]

161. Holbein, W.W.; Bardgett, M.E.; Toney, G.M. Blood pressure is maintained during dehydration by hypothalamic paraventricular nucleus-driven tonic sympathetic nerve activity. J. Physiol. 2014, 592, 3783-3799. [CrossRef]

162. Stocker, S.D.; Lang, S.M.; Simmonds, S.S.; Wenner, M.M.; Farquhar, W.B. Cerebrospinal Fluid Hypernatremia Elevates Sympathetic Nerve Activity and Blood Pressure via the Rostral Ventrolateral Medulla. Hypertension 2015, 66, 1184-1190. [CrossRef]

163. Scrogin, K.E.; Grygielko, E.T.; Brooks, V.L. Osmolality: A physiological long-term regulator of lumbar sympathetic nerve activity and arterial pressure. Am. J. Physiol. 1999, 276, 1579. [CrossRef]

164. Colombari, D.S.A.; Colombari, E.; Freiria-Oliveira, A.H.; Antunes, V.R.; Yao, S.T.; Hindmarch, C.; Ferguson, A.V.; Fry, M.; Murphy, D.; Paton, J.F.R. Switching control of sympathetic activity from forebrain to hindbrain in chronic dehydration. J. Physiol. 2011, 589, 4457-4471. [CrossRef]

165. Veitenheimer, B.J.; Engeland, W.C.; Guzman, P.A.; Fink, G.D.; Osborn, J.W. Effect of global and regional sympathetic blockade on arterial pressure during water deprivation in conscious rats. Am. J. Physiol. Heart Circ. Physiol. 2012, 303, 1022. [CrossRef] 
166. Grassi, G.; Seravalle, G.; Brambilla, G.; Pini, C.; Alimento, M.; Facchetti, R.; Spaziani, D.; Cuspidi, C.; Mancia, G. Marked sympathetic activation and baroreflex dysfunction in true resistant hypertension. Int. J. Cardiol. 2014, 177, 1020-1025. [CrossRef]

167. James, M.A.; Robinson, T.G.; Panerai, R.B.; Potter, J.F. Arterial baroreceptor-cardiac reflex sensitivity in the elderly. Hypertension 1996, 28, 953-960. [CrossRef]

168. Ebert, T.J.; Morgan, B.J.; Barney, J.A.; Denahan, T.; Smith, J.J. Effects of aging on baroreflex regulation of sympathetic activity in humans. Am. J. Physiol. 1992, 263, 798. [CrossRef]

169. Filomena, J.; Riba-Llena, I.; Vinyoles, E.; Tovar, J.L.; Mundet, X.; Castane, X.; Vilar, A.; Lopez-Rueda, A.; Jimenez-Balado, J.; Cartanya, A.; et al. ISSYS Investigators Short-Term Blood Pressure Variability Relates to the Presence of Subclinical Brain Small Vessel Disease in Primary Hypertension. Hypertension 2015, 66, 634-640. [CrossRef]

170. Mancia, G.; Parati, G.; Hennig, M.; Flatau, B.; Omboni, S.; Glavina, F.; Costa, B.; Scherz, R.; Bond, G.; Zanchetti, A. Relation between blood pressure variability and carotid artery damage in hypertension: Baseline data from the European Lacidipine Study on Atherosclerosis (ELSA). J. Hypertens. 2001, 19, 1981-1989. [CrossRef]

171. Madden, J.M.; O’Flynn, A.M.; Dolan, E.; Fitzgerald, A.P.; Kearney, P.M. Short-term blood pressure variability over $24 \mathrm{~h}$ and target organ damage in middle-aged men and women. J. Hum. Hypertens. 2015, 29, 719-725. [CrossRef]

172. Palatini, P.; Penzo, M.; Racioppa, A.; Zugno, E.; Guzzardi, G.; Anaclerio, M.; Pessina, A.C. Clinical relevance of nighttime blood pressure and of daytime blood pressure variability. Arch. Intern. Med. 1992, 152, 1855-1860. [CrossRef]

173. Ogawa, Y.; Iwasaki, K.; Aoki, K.; Saitoh, T.; Kato, J.; Ogawa, S. Dynamic cerebral autoregulation after mild dehydration to simulate microgravity effects. Aviat. Space Environ. Med. 2009, 80, 443-447. [CrossRef]

174. Matsukawa, T.; Gotoh, E.; Minamisawa, K.; Kihara, M.; Ueda, S.; Shionoiri, H.; Ishii, M. Effects of intravenous infusions of angiotensin II on muscle sympathetic nerve activity in humans. Am. J. Physiol. 1991, 261, 690. [CrossRef]

175. Trapani, A.J.; Undesser, K.P.; Keeton, T.K.; Bishop, V.S. Neurohumoral interactions in conscious dehydrated rabbit. Am. J. Physiol. 1988, 254, 338. [CrossRef]

176. Charkoudian, N.; Halliwill, J.R.; Morgan, B.J.; Eisenach, J.H.; Joyner, M.J. Influences of hydration on post-exercise cardiovascular control in humans. J. Physiol. 2003, 552, 635-644. [CrossRef]

177. Andrews, C.E., Jr.; Brenner, B.M. Relative contributions of arginine vasopressin and angiotensin II to maintenance of systemic arterial pressure in the anesthetized water-deprived rat. Circ. Res. 1981, 48, 254-258. [CrossRef]

178. Carroll, H.A.; James, L.J. Hydration, Arginine Vasopressin, and Glucoregulatory Health in Humans: A Critical Perspective. Nutrients 2019, 11, 1201. [CrossRef]

179. Johnston, C. Vasopressin in Circulatory Control and Hypertension. J. Hyper. 1985, 3, 557-569. [CrossRef]

180. Liard, J.F. Vasopressin in cardiovascular control: Role of circulating vasopressin. Clin. Sci. 1984, 67, $473-481$. [CrossRef]

181. Flynn, F.W.; Stricker, E.M. Hypovolemia stimulates intraoral intake of water and $\mathrm{NaCl}$ solution in intact rats but not in chronic decerebrate rats. Physiol. Behav. 2003, 80, 281-287. [CrossRef]

182. Collister, J.P.; Nahey, D.B.; Hendel, M.D.; Brooks, V.L. Roles of the subfornical organ and area postrema in arterial pressure increases induced by 48-h water deprivation in normal rats. Physiol. Rep. 2014, 2, e00191. [CrossRef]

183. Tyagi, M.G.; Thomas, M. Enhanced cardiovascular reactivity to desmopressin in water-restricted rats: Facilitatory role of immunosuppression. Methods Find. Exp. Clin. Pharmacol. 1999, 21, 619-624.

184. Hiwatari, M.; Johnston, C.I. Involvement of vasopressin in the cardiovascular effects of intracerebroventricularly administered alpha 1-adrenoceptor agonists in the conscious rat. J. Hyper. 1985, 3, 613. [CrossRef]

185. Brooks, V.L. Vasopressin and ANG II in the control of ACTH secretion and arterial and atrial pressures. Am. J. Physiol. 1989, 256, 339. [CrossRef]

186. Schreihofer, A.M.; Stricker, E.M.; Sved, A.F. Chronic nucleus tractus solitarius lesions do not prevent hypovolemia-induced vasopressin secretion in rats. Am. J. Physiol. 1994, 267, 965. [CrossRef] 
187. Fejes-Tóth, G.; Náray-Fejes-Tóth, A.; Ratge, D. Evidence against role of antidiuretic hormone in support of blood pressure during dehydration. Am. J. Physiol. 1985, 249. [CrossRef]

188. Huch, K.M.; Wall, B.M.; Mangold, T.A.; Bobal, M.A.; Cooke, C.R. Hemodynamic response to vasopressin in dehydrated human subjects. J. Investig. Med. 1998, 46, 312-318.

189. Wenner, M.M.; Stachenfeld, N.S. Blood pressure and water regulation: Understanding sex hormone effects within and between men and women. J. Physiol. 2012, 590, 5949-5961. [CrossRef]

190. Stachenfeld, N.S.; Silva, C.; Keefe, D.L.; Kokoszka, C.A.; Nadel, E.R. Effects of oral contraceptives on body fluid regulation. J. Appl. Physiol. 1999, 87, 1016-1025. [CrossRef]

191. Minson, C.T.; Halliwill, J.R.; Young, T.M.; Joyner, M.J. Influence of the menstrual cycle on sympathetic activity, baroreflex sensitivity, and vascular transduction in young women. Circulation 2000, 101, 862-868. [CrossRef]

192. Carter, J.R.; Lawrence, J.E.; Klein, J.C. Menstrual cycle alters sympathetic neural responses to orthostatic stress in young, eumenorrheic women. Am. J. Physiol. Endocrinol. Metab. 2009, 297, 85. [CrossRef]

193. Fu, Q.; Okazaki, K.; Shibata, S.; Shook, R.P.; VanGunday, T.B.; Galbreath, M.M.; Reelick, M.F.; Levine, B.D. Menstrual cycle effects on sympathetic neural responses to upright tilt. J. Physiol. 2009, 587, 2019-2031. [CrossRef]

194. Baker, S.E.; Limberg, J.K.; Ranadive, S.M.; Joyner, M.J. Neurovascular control of blood pressure is influenced by aging, sex, and sex hormones. Am. J. Physiol. Regul. Integr. Comp. Physiol. 2016, 311, R1275. [CrossRef]

195. Harvey, R.E.; Hart, E.C.; Charkoudian, N.; Curry, T.B.; Carter, J.R.; Fu, Q.; Minson, C.T.; Joyner, M.J.; Barnes, J.N. Oral Contraceptive Use, Muscle Sympathetic Nerve Activity, and Systemic Hemodynamics in Young Women. Hypertension 2015, 66, 590-597. [CrossRef]

196. Claydon, V.E.; Younis, N.R.; Hainsworth, R. Phase of the menstrual cycle does not affect orthostatic tolerance in healthy women. Clin. Auton. Res. 2006, 16, 98-104. [CrossRef]

197. Lawrence, J.E.; Ray, C.A.; Carter, J.R. Vestibulosympathetic reflex during the early follicular and midluteal phases of the menstrual cycle. Am. J. Physiol. Endocrinol. Metab. 2008, 294, 1046. [CrossRef]

198. Robinson, A.T.; Babcock, M.C.; Watso, J.C.; Brian, M.S.; Migdal, K.U.; Wenner, M.M.; Farquhar, W.B. Relation between resting sympathetic outflow \& vasoconstrictor responses to sympathetic nerve bursts: Sex differences in healthy young adults. Am. J. Physiol. Regul. Integr. Comp. Physiol. 2019. [CrossRef]

199. Thompson, W.O.; Thompson, P.K.; Dailey, M.E. The Effect of Posture upon the Composition and Volume of the Blood in Man. J. Clin. Invest. 1928, 5, 573-604. [CrossRef]

200. Fedorowski, A.; Burri, P.; Melander, O. Orthostatic hypotension in genetically related hypertensive and normotensive individuals. J. Hypertens. 2009, 27, 976-982. [CrossRef]

201. Ricci, F.; De Caterina, R.; Fedorowski, A. Orthostatic Hypotension: Epidemiology, Prognosis, and Treatment. J. Am. Coll. Cardiol. 2015, 66, 848-860. [CrossRef]

202. Sheldon, R.S.; Grubb, B.P.; Olshansky, B.; Shen, W.; Calkins, H.; Brignole, M.; Raj, S.R.; Krahn, A.D.; Morillo, C.A.; Stewart, J.M.; et al. 2015 heart rhythm society expert consensus statement on the diagnosis and treatment of postural tachycardia syndrome, inappropriate sinus tachycardia, and vasovagal syncope. Heart Rhythm. 2015, 12. [CrossRef]

203. Cooke, W.H.; Ryan, K.L.; Convertino, V.A. Lower body negative pressure as a model to study progression to acute hemorrhagic shock in humans. J. Appl. Physiol. 2004, 96, 1249-1261. [CrossRef]

204. Hinojosa-Laborde, C.; Shade, R.E.; Muniz, G.W.; Bauer, C.; Goei, K.A.; Pidcoke, H.F.; Chung, K.K.; Cap, A.P.; Convertino, V.A. Validation of lower body negative pressure as an experimental model of hemorrhage. J. Appl. Physiol. 2014, 116, 406-415. [CrossRef]

205. Cheshire, W.P.; Goldstein, D.S. Autonomic uprising: The tilt table test in autonomic medicine. Clin. Auton. Res. 2019, 29, 215-230. [CrossRef]

206. Goswami, N.; Blaber, A.P.; Hinghofer-Szalkay, H.; Convertino, V.A. Lower Body Negative Pressure: Physiological Effects, Applications, and Implementation. Physiol. Rev. 2019, 99, 807-851. [CrossRef]

207. Thompson, C.A.; Tatro, D.L.; Ludwig, D.A.; Convertino, V.A. Baroreflex responses to acute changes in blood volume in humans. Am. J. Physiol. 1990, 259, 792. [CrossRef]

208. Cheuvront, S.N.; Ely, B.R.; Kenefick, R.W.; Buller, M.J.; Charkoudian, N.; Sawka, M.N. Hydration assessment using the cardiovascular response to standing. Eur. J. Appl. Physiol. 2012, 112, 4081-4089. [CrossRef]

209. Kimmerly, D.S.; Shoemaker, J.K. Hypovolemia and MSNA discharge patterns: Assessing and interpreting sympathetic responses. Am. J. Physiol. Heart Circ. Physiol. 2003, 284, 1198. [CrossRef] 
210. Brooks, V.L.; Freeman, K.L.; Clow, K.A. Excitatory amino acids in rostral ventrolateral medulla support blood pressure during water deprivation in rats. Am. J. Physiol. Heart Circ. Physiol. 2004, 286, 1642. [CrossRef]

211. Brooks, V.L.; Qi, Y.; O’Donaughy, T.L. Increased osmolality of conscious water-deprived rats supports arterial pressure and sympathetic activity via a brain action. Am. J. Physiol. Regul. Integr. Comp. Physiol. 2005, 288, 1248. [CrossRef]

212. Watso, J.C.; Babcock, M.C.; Robinson, A.T.; Migdal, K.U.; Wenner, M.M.; Stocker, S.D.; Farquhar, W.B. Water deprivation does not augment sympathetic or pressor responses to sciatic afferent nerve stimulation in rats or to static exercise in humans. J. Appl. Physiol. 2019. [CrossRef]

213. Riley, C.J.; Gavin, M. Physiological Changes to the Cardiovascular System at High Altitude and Its Effects on Cardiovascular Disease. High Alt. Med. Biol. 2017, 18, 102-113. [CrossRef]

214. Jain, S.C.; Bardhan, J.; Swamy, Y.V.; Krishna, B.; Nayar, H.S. Body fluid compartments in humans during acute high-altitude exposure. Aviat. Space Environ. Med. 19809, 51, 234-236.

215. annheimer, M.; Fusch, C.; Boning, D.; Thomas, A.; Engelhardt, M.; Schmidt, R. Changes of hematocrit and hemoglobin concentration in the cold Himalayan environment in dependence on total body fluid. Sleep Breath. 2010, 14, 193-199. [CrossRef]

216. Frayser, R.; Rennie, I.D.; Gray, G.W.; Houston, C.S. Hormonal and electrolyte response to exposure to 17,500 ft. J. Appl. Physiol. 1975, 38, 636-642. [CrossRef]

(C) 2019 by the authors. Licensee MDPI, Basel, Switzerland. This article is an open access article distributed under the terms and conditions of the Creative Commons Attribution (CC BY) license (http://creativecommons.org/licenses/by/4.0/). 